\title{
Rosiglitazone Maleate
}

National Cancer Institute

\section{Source}

National Cancer Institute. Rosiglitazone Maleate. NCI Thesaurus. Code C2583.

The maleate salt of rosiglitazone, an orally-active thiazolidinedione with antidiabetic properties and potential antineoplastic activity. Rosiglitazone activates peroxisome proliferator-activated receptor gamma (PPAR-gamma), a lig and-activated transcription factor, thereby inducing cell differentiation and inhibiting cell growth and angiogenesis. This agent also modulates the transcription of insulin-responsive genes, inhibits macrophage and monocyte activation, and stimulates adipocyte differentiation. 